\title{
Transfer czy osmoza? Literatura polska w angloamerykańskiej literaturze światowej
}

\section{Transfer or Osmosis? Polish Literature and the Anglo-American World Literature}

Abstract: The article addresses the problem of cultural transfer, first, by defining its conditions, and, secondly, by asking about the criteria by which we can measure its success. Among the latter, one can mention the impact of the translated work on the target language literature, the critical reception of the work, and on its author's presence in the public space of the foreign culture. The successfully transferred work becomes an element of "world literature," constituted differently in different cultures. The article discusses these issues by analyzing specific examples of translations of contemporary Polish literature into English and various forms of their presence in the Anglophone world. Special attention is paid not only to the influence these translations have on the literature of the target language, but also on the ways in which they are in turn affected by their new cultural and linguistic environment. Cultural transfer is thus seen as a process of multidirectional osmosis, in effect of which both the translated work and foreign literature are modified.

Keywords: literary translation, cultural transfer, contemporary Polish literature, world literature

Streszczenie: Podjęty w artykule problem transferu kulturowego przybiera najpierw postać pytania o warunki udanego przeszczepienia dzieł literackich, a następnie o kryteria jego oceny. Wśród tych ostatnich autor wyróżnia trzy: wpływ przełożonego dzieła na literaturę języka przekładu, jego krytyczną recepcję oraz udział autora w debatach publicznych. Przeszczepione z sukcesem dzieło staje się elementem „literatury światowej”, kształtowanej jednak zawsze w obrębie określonej (tu: angloamerykańskiej) kultury. Zagadnienia te omówione zostają na konkretnych przykładach tłumaczeń współczesnej literatury polskiej na angielski i formach jej obecności w kulturze angloamerykańskiej, przy czym w centrum uwagi znajduje się nie tylko oddziaływanie przekładów na literaturę kultury docelowej, ale także wpływ tej literatury na przełożone dzieło. Bowiem transfer kulturowy to proces wielokierunkowej osmozy, w którego wyniku zmienia się i dzieło, i jego nowe środowisko. Słowa kluczowe: przekład literacki, transfer kulturowy, współczesna literatura polska, literatura światowa 
Mechanizmy transferów kulturowych, a zwłaszcza kwestia warunków ich skuteczności, są o tyle nieuchwytne, że składają się na nie złożone, wielorakie, trudne bądź niemożliwe do zdefiniowania czynniki, w każdym poszczególnym przypadku układające się w inną konstelację. Możemy co najwyżej mówić wybiórczo: o czynnikach dominujących albo uświadomionych, to znaczy tych, których opis wszedł do języka krytyki. Tę nieuchwytność przyczyn, dla których jedne dzieła przebijają się do obcych kultur i wchodzą do literatury światowej, a inne, tej samej rangi i w podobnych warunkach - nie, można oczywiście nazwać przypadkiem. Nie zamknęłoby to jednak dyskusji, wprowadziłoby zaś jałową kategorię tajemnicy.

Przykładem niech będzie tu historia recepcji poezji Zbigniewa Herberta w krajach anglojęzycznych, prawdopodobnie największego na tym obszarze sukcesu powojennej literatury polskiej: każdemu z tego obszaru, kto interesuje się poezją, Herbert będzie znany, nie każdemu zainteresowanemu powieścią znany będzie Stanisław Lem czy Witold Gombrowicz. Przy czym zainteresowaniu Herbertem towarzyszyła szczególnego rodzaju moda na poezję wschodnioeuropejską, która rozwinęła się w latach sześćdziesiątych. Trudno określić, w jakim stopniu moda ta przyczyniła się do popularności Herberta, a w jakim wyjątkowość Herberta wpłynęła na rozkwit tej mody, jedno jest pewne, że te dwa zjawiska wzajem się wspierały. Oba też, co oczywiste, wiązały się z ówczesnymi podziałami politycznymi bardziej niż z powinowactwem poetyk. Jak bowiem inaczej wytłumaczyć, że krytyka brytyjska wrzuciła do jednego worka kilku poetów z tej części Europy, w przekonaniu, że stanowią oni reprezentację jakiejś spójnej, choć w istocie całkiem iluzorycznej „dykcji wschodnioeuropejskiej”? Co mieli wspólnego Herbert z Węgrem Jánosem Pilinszkym, a Czech Miroslav Holub z Serbem Vasko Popą innego niż obywatelstwo któregoś z państw bloku wschodniego? Herberta do dziś, w kilka dekad po upadku żelaznej kurtyny, przedstawia się w mainstreamowych anglojęzycznych edycjach jego prac jako „duchowego przywódcę antykomunistycznego ruchu w Polsce”.

A jednak przyczyn popularności Herberta w krajach anglosaskich, do dziś bezprecedensowej, nie można sprowadzić do zimnowojennego układu sił, bo układ ten innego niż Herbert poety polskiego nie wylansował. Herbert wszedł do angielszczyzny w momencie dla poezji brytyjskiej szczególnym, bo krytycznym, co także miało znaczący wpływ na jego popularność: Herbert był po prostu potrzebny Brytyjczykom, którzy w tym właśnie czasie czuli, że ich poezja gryzie własny ogon i obniża loty. Krytyk Alfred Alvarez, jeden z najbardziej aktywnych sojuszników polskiego pisarza w Wielkiej Brytanii, nie wahał się napisać: „wiersze Herberta, nawet po angielsku, wydają mi się doskonalsze niż cokolwiek, co obecnie pisze jakikolwiek angielski czy amerykański poeta”2 . Jeśli jednak Alvarez chwalił Herberta za świadomość historyczną, nieobecną ponoć

1 Por. Z. Herbert, The Collected Poems 1956-1998, tłum., red. A. Valles, New York 2007.

2 Recenzja cytowana na okładce - zob. tamże. 
w twórczości ówczesnych poetów brytyjskich, to tym bardziej powinien zafascynować się pisarstwem Tadeusza Różewicza, tymczasem znajomość twórczości autora Kartoteki, mimo wielu przekładów, jest w krajach angielskojęzycznych minimalna. Do skuteczności transferu poezji Herberta z pewnością przyczyniła się jej względna, czy tylko pozorna przekładalność, problemy przekładowe stały się z kolei zaporą, jeśli nie uniemożliwiającą, to znakomicie utrudniającą przebicie się do anglojęzycznego czytelnika takich poetów jak Bolesław Leśmian czy Miron Białoszewski. Względna łatwość przekładu przywołanemu tu Różewiczowi jednak niczego nie zagwarantowała.

A więc, po pierwsze, zimna wojna, czyli kontekst pozaliteracki, polityczny; po drugie, kryzys poezji brytyjskiej, czyli kontekst literatury języka przekładu; po trzecie, cechy tłumaczonej twórczości, takie jak świadomość historii i kulturowego dziedzictwa, moralne przesłanie wierszy, ich przekładalność; a wreszcie po czwarte, sprawność promocji i ranga promotorów. Każdy z tych czynników, zewnętrznych lub wewnętrznych, przysłużył się popularności Herberta, żaden jednak nie wystarczał, by zapewnić innym polskim poetom podobną jak Herbertowi karierę w świecie anglojęzycznym.

Przeglądając historię najbardziej bodaj owocnych przemieszczeń w trzech dziedzinach sztuki - poezja Herberta, filmy Krzysztofa Kieślowskiego, muzyka Henryka Mikołaja Góreckiego - można wysnuć wniosek, że kultura angloamerykańska szuka tego, co u niej samej jest nieobecne. Właśnie dlatego przemieszczone dzieła trzech wymienionych twórców pozostają naznaczone obcością. To, co trzyma je przy życiu w obcym im kulturowo otoczeniu, to różnica. I to różnica znacząca, wyraźnie egzotyzująca. Wspomniane transfery to momenty, w których kultura anglojęzyczna otworzyła się na to, co u niej byłoby nie do pomyślenia, uznane za anachroniczne czy pretensjonalne. W poezji języka angielskiego głos Herberta, faworyzujący postawę klasyczną, akcentujący ciągłość i ważkość dziedzictwa kulturowego, wnioskujący o poezję o jednoznacznej wymowie moralnej, z podmiotem rozmawiającym z Rolandem i Gilgameszem, spotkałby się, zwłaszcza w kontestujących latach sześćdziesiątych, z jawną, bezwzględną krytyką. „Spotkałby się” - jestem świadom, że używam trybu warunkowego i buduję hipotezę, której wartość jednak zasadza się na obserwacji, że ani przed Herbertem, ani po Herbercie nie pojawił się w poezji anglojęzycznej głos „herbertowski”. Herbert, mimo swojej (ideowej raczej niż estetycznej) fascynacji T.S. Eliotem, był w tamtej tradycji „obcym": nie miał poprzedników.

O zaskakującej popularności filmów Kieślowskiego w Wielkiej Brytanii pisałem już gdzie indziej, tu powtórzę, że ich metafizyka leży na przeciwległym biegunie tego, na co mogli sobie pozwolić filmowcy brytyjscy - w dziele tym Kieślowskiego wyprzedził Andriej Tarkowski. Zwrócił na to uwagę Tadeusz Lubelski w artykule o francuskiej recepcji filmów reżysera Dekalogu, łącząc „modę na Kieślowskiego z pewnym kontekstem dzisiejszej francuskiej kultury: zauroczeniem mistyką i Europą Wschodnią," przywołując w tym kontekście 
słowa Antoine’a de Baecque’a: „Moda? Ależ to cały kościół i to gromadzący sporo wiernych. Tarkowski, Kieślowski - rosyjski mistyk i Polak komentujący Stary Testament - zastępczo zaspokajają dwie wielkie potrzeby sporej części publiczności we Francji: wiary i egzotyki”3. Wyjaśniając różnicę między recepcją Kieślowskiego w Polsce i we Francji, Lubelski dopowiada: „Nas rodzima tradycja już tym przekarmiła. Dla Francuzów to obce i kuszące. I wciąż chętnie się łudzą, że tego szaleństwa dotkną, jak nie w Rosjaninie, to w Polaku” ‘. To, co Lubelski mówi o Francuzach, równie trafnie wyjaśnia zachowanie Brytyjczyków: kusi ich to, co obce i różne. Podobnie z muzyką, zaspokajającą głód „wiary i egzotyki”. Jawnie sakralny wymiar trzeciej symfonii Góreckiego jest w kulturze anglosaskiej zjawiskiem wyjątkowym - współczesna muzyka brytyjska nieczęsto wnika w te obszary, jedyny bodaj kompozytor zbliżony do tego typu sakralności, John Tavener, sam poddał się szczególnej egzotyzacji, przechodząc na prawosławie i w muzyce cerkiewnej szukając inspiracji. Zaszczepienie Herberta, Kieślowskiego czy Góreckiego w kulturze anglojęzycznej (choć nie tylko tam) jest buforowane ich obcością - w oczach Brytyjczyków wymienieni twórcy mogą sobie na taką poetykę pozwolić, ponieważ przychodzą z tego drugiego świata, nie tyle nawet zza żelaznej kurtyny, ile z doświadczonej historią Europy Wschodniej. Kuszą tym, co kultura brytyjska z siebie wyparła czy w sobie przezwyciężyła: skłonność do mistycyzmu, metafizyczne ciągoty, wiarę w sensotwórczy wymiar cierpienia.

Anglojęzyczny świat się w tych dziełach, choć wysoko je wynosi, nie przegląda, bo jest - w swoim mniemaniu - na innym etapie kulturowego rozwoju. Lub, jak kto woli, kulturowej degradacji. Stając przed nimi, staje wobec czegoś innego, bardziej autentycznego, pierwotniejszego niż jego własna kultura. Próby sprzedaży za granicą dzieł kultury polskiej, które idą tropem osiągnięć Zachodu, kończą się niepowodzeniem. Przykładem może być musical „Metro", który w Polsce odniósł bezprzykładny sukces, a pokazany w Nowym Jorku poniósł dotkliwą klęskę. Nie zainteresują tam nikogo doskonałe pod wieloma względami podróbki Żądta w wykonaniu Juliusza Machulskiego, czyli oba Vabanki, bo są właśnie podróbkami hollywoodzkiego hitu. Z innego poziomu sztuki przywołajmy Tadeusza Kantora, którego malarstwo, wyrosłe z fascynacji zachodnią awangardą, u nas oddziałało inspirująco, na Zachodzie nie spotkało się z większym zaciekawieniem. Amerykanów nie zainteresuje Marek Hłasko, bo literaturę obyczajowej kontestacji i egzystencjalnego ryzyka od lat mają u siebie w najlepszym wydaniu. I wreszcie nie zainteresuje ich nowa poezja polska powstająca po 1989 roku, choćby najwyższych lotów, i tak różna jak wiersze Andrzeja Sosnowskiego, Marcina Świetlickiego, Jacka Podsiadły, ponieważ się zuniwersalizowała, stała się bardziej światowa, bardziej podobna

3 T. Lubelski, Prawdziwy partner. Francuska krytyka o Kieślowskim, „Kwartalnik Filmowy" 1993, nr 4, s. 126.

4 Tamże. 
do tego, co pisze się od dłuższego czasu w Ameryce czy w Anglii. Z kolei poezja twórców kontynuujących tradycję, przywołajmy tę nazwę, „szkoły polskiej", takich jak Adam Zagajewski czy, toutes proportions gardées, młodszy niemal o dwa pokolenia Tadeusz Dąbrowski, choć publikowana w prestiżowych pismach i wydawnictwach, nie wzbudza żywszego zainteresowania: jest przyjmowana i czytana, bo spełnia angloamerykańskie wyobrażenia tego, jak piszą rodacy Herberta, ale już nie pobudza.

W dyskusji nad kulturowym przemieszczeniem pytanie o jego warunki i przyczyny jest jednak pytaniem mniej ciekawym od tego, co to rzeczywiście znaczy, że dzieło zaistniało w obcej kulturze. Jakie są kryteria, które pozwoliłyby nam odpowiedzieć na pytanie, czy transfer się powiódł? Jak ocenić, czy tłumaczona na języki obce literatura polska, a więc literatura po przemieszczeniu, rzeczywiście funkcjonuje w literaturze światowej? Wydawałoby się, że obiektywnie takim kryterium mogłyby być międzynarodowe nagrody. Autor lub autorka uhonorowani Bookerem czy Noblem wchodzą do historii - mają gwarantowane miejsca w dziejach tych międzynarodowych nagród, a tym samym w kronikach literatury światowej. Ale bez trudu można przytoczyć przykłady laureatów największych światowych nagród, którzy mimo owych laurów nie istnieją - nazwisko D.B.C. Pierre’a, który otrzymał Bookera w 2003 roku, nawet wyrobionym czytelnikom niewiele powie. Nagrodzeni Noblem w 1974 roku Harry Martinsson i Eyvind Johnson są faktycznie w Polsce nieobecni, a na pewno nieczytani. Nobel dla Reymonta nie zagwarantował autorowi niczego, ani kolejnych wydań jego książek, ani choćby obecności w świadomości czytelniczej.

Gdyby oceniać skuteczność kulturowego transferu miarą międzynarodowych nagród, wtedy pośród współczesnych polskich autorów szczególne miejsce należałoby się Wioletcie Grzegorzewskiej, nominowanej w 2017 roku do Nagrody Man Booker International Prize za tom prozy Guguty - była to druga nominacja dla autorów z Polski (po Lemie w 2005 roku). Po niej, przypomnijmy, przyszła dwukrotna nominacja dla Olgi Tokarczuk (2018 i 2019 rok), pierwsza z nich uwieńczona laurem. Dwa lata wcześniej Grzegorzewska zyskała nominację do innej, tym razem poetyckiej, międzynarodowej nagrody, Griffin Poetry Prize - przed nią polską poezję reprezentowali tam jedynie Tadeusz Różewicz i Tomasz Różycki (w 2016 roku nagrodę za całokształt odebrał Adam Zagajewski). Popatrzmy, jak wygląda polska literatura według pierwszej nagrody: Lem, Grzegorzewska, Tokarczuk, w kontekście drugiej: Różewicz, Różycki, Grzegorzewska, Zagajewski. Dwie nominacje, które autorka uzyskała w Polsce (do Nike i do Nagrody Literackiej Gdynia), wypadają blado wobec rangi wyróżnień w świecie anglojęzycznym, a jednak międzynarodowe laury nie wystarczyły, by mieszkająca od wielu lat w Wielkiej Brytanii pisarka, która tymczasem zanglicyzowała swoje nieprzystępne Anglikom nazwisko i dziś podpisuje się Greg, weszła do współczesnej literatury światowej. 
Przy wielkim rozproszeniu ruchu wydawniczego oraz łatwości, z jaką można dziś tanio wydać książkę, często nie potrafimy ocenić stopnia przemieszczenia konkretnego dzieła. O udanym przemieszczeniu możemy mówić wtedy, gdy spełnią się niektóre z warunków. Wymieniłbym wśród nich, poza międzynarodowymi prestiżowymi nagrodami, także prestiż wydawców. Brytyjskie wydawnictwo Arc, małe (16 tytułów rocznie) i niezależne, wydaje serię „Widzialni Poeci”, w której przekłady wierszy drukowane są równolegle z ich wersjami oryginalnymi - co w zamierzeniu ma przypomnieć czytelnikom, że mają do czynienia z przekładami. W serii znajdziemy poezję turecką, duńską, japońską, łotewską, indonezyjską, algierską, baskijską, tamilską itd. Wystarczy, żeby zorientować się, że pomysłem na serię jest publikowanie wierszy z obszarów niemal zupełnie w świadomości czytelniczej Anglika czy Amerykanina nieobecnych, tu szuka się nie tyle najważniejszych dokonań poetyckich, ile jak najszerszej językowo, wolnej od europocentryzmu, reprezentacji poezji światowej. Nie ujmuję nic tej inicjatywie, ale oczywiste jest, że wydawca, promując nieznane nazwiska, otwierając język angielski na dokonania obcojęzycznych poetów z dyskryminowanych czy lekceważonych obszarów, jednocześnie tworzy dla nich swoiste getto. Wydobywa ich z zamkniętych lokalnych kontekstów i zamyka ponownie w anglojęzycznym rezerwacie. Przedstawia w specjalnie dla nich wymyślonej serii, przypominając tym samym, że ci poeci w innych seriach nie mieliby szans. Twórcy ci nie stają się koleżankami czy kolegami po fachu poetów języka angielskiego ani poetów literatury światowej. Nie startują w tej samej kategorii wagowej. Wykrojony został dla nich obszar, który mogą odwiedzać czytelnicy zainteresowani obcojęzyczną poezją z Algierii, z kraju Basków czy ze Sri Lanki (pamiętamy tę protekcjonalną frazę z wiersza Franka O’Hary w przekładzie Piotra Sommera: „i kupuję/ szpetnie wydanych PISARZY TRZECIEGO ŚWIATA żeby zobaczyć co tam/ ostatnio słychać u poetów w Ghanie" ”). Tom wierszy Krystyny Miłobędzkiej, który ukazał się w takiej serii i takim wydawnictwie, ze wsparciem finansowym Unii Europejskiej i polskiego Instytutu Książki, ma zupełnie inną siłę rażenia niż książka Adama Zagajewskiego, która została opublikowana (jako jedyna, oprócz tomu Szymborskiej, książka żyjącego polskiego poety) w londyńskiej serii poetyckiej wydawnictwa Faber and Faber. Zagajewski ukazuje się tu obok Eliota, W.H. Audena, Roberta Lowella, Seamusa Heaneya - namacalny znak, że znalazł się w kulturowym głównym nurcie; Miłobędzka tymczasem obok Antonio Moury, Birhana Keskina i Cherana (wybieram losowo trzy ostatnie nazwiska z serii). Moura może być pod wieloma względami ciekawszym poetą niż Eliot, ale w świecie anglojęzycznym to Eliot uwierzytelnia opublikowanych w tej samej serii poetów. Renoma oficyny wydawniczej nie powinna wpływać na ocenę publikowanej przez nią literatury, niemniej jednak już samo wydanie przekładu

5 F. O’Hara, Twoja pojedynczość, wybór, tłum., posłowie P. Sommer, Warszawa 1987, s. 68. 
w dużym wydawnictwie i prestiżowej serii jest - jak nazywa to Lawrence Venuti - „gestem kanonizującym”.

Omawiam tu sytuację książki poetyckiej, ale ten sam mechanizm działa też w przypadku prozy. Największy sukces transferowy w powojennej literaturze polskiej (pomijam Noble) to, obok Lema, z pewnością Ryszard Kapuściński - wszystkie jego książki publikuje oficyna Penguin Books, wyraźny sygnał, że to nazwisko należy już do literatury światowej. Również w Penguin Books ukazał się niedawno angielskojęzyczny przekład opowiadania Kornela Filipowicza, Pamiętnik Antybohatera (w serii Penguin Classics obok książek Swietłany Aleksijewicz, Georges'a Simenona, Yukio Mishimy, Romain Gary’ego), co ciekawe - okładkę zdobi grafika Kazimierza Mikulskiego. Publikacje tej miary to, powtórzmy, przykłady kanonizacji: nie tyle odzwierciedlają, ile tworzą kanon literatury światowej.

Wpisanie autora do takiego kanonu może nastąpić w wyniku osłabienia jego narodowej, kulturowej czy językowej przynależności, gdy rodzi się poczucie, że można go czytać bez konieczności sięgania po kontekst lokalny, w towarzystwie światowych i rodzimych klasyków, a nie równie egzotycznych (używam tego słowa świadomie) kolegów po piórze. W amerykańskich edycjach Solaris (2002), Kosmosu (2005) czy Pornografii (2009) wydawcy nie informują, że autorami byli polscy pisarze - nie ma takiej potrzeby w przypadku twórców literatury światowej (tak jak nie ma konieczności, bym czytelnikom polskim podawał nazwiska tych autorów - kto nie wie, kim jest autor Solaris czy Kosmosu, na pewno nie czytałby mojego tekstu). Egzotyzm tej twórczości nie zanika, dzieło nadal pracuje różnicą, ale ta różnica postrzegana jest w relacji do oswojonej już obcości dzieł klasycznych.

Wobec rozmaitych definicji literatury światowej czy głosów podających w wątpliwość jej istnienie ${ }^{7}$ proponuję roboczo przyjąć, że na literaturę światową składają się dzieła kulturowo przemieszczone, których lektura nie wymaga znajomości ich pierwotnego, macierzystego kontekstu kulturowego ani wytworzonych w ich macierzystym języku komentarzy, przywołań i nawiązań, są bowiem oświetlane literaturą i krytyką, które powstały i nieustannie powstają w innych językach i kulturach, a zwłaszcza w kulturze „naszej”, rodzimej. Piszę „naszej” nie bez powodu - literatura światowa mimo nazwy istnieje zawsze w relacji do konkretnej kultury. Jak przypomina Justin Quinn, nie ma literatury światowej w ogóle, jest literatura światowa w wersji polskiej, literatura światowa w wersji amerykańskiej, w wersji francuskiej: „literatura światowa nie jest przestrzenią wspólną, do której mają dostęp wszystkie narody, ale cechą indywidualną każdego poszczególnego narodu"8.

6 L. Venuti, The Translator's Invisibility: A History of Translation, London 1995, s. 283.

J. Quinn, Between Two Fires: Transnationalism and Cold War Poetry, Oxford 2015, s. $13-21$.

8 Tamże, s. 17. 
Literaturę światową w kulturze angloamerykańskiej tworzą, co nikogo nie zaskoczy, dzieła przede wszystkim angielskojęzyczne - w Bloomowskim kanonie na 26 pisarzy połowa to twórcy języka angielskiego. To, że kultura dominująca, jaką jest świat anglojęzyczny, będzie literaturę raczej eksportować niż importować, traktując ją jako towar i element kulturowej ekspansji, uznaje się za oczywistość. Venuti, przypominając, że przekłady stanowią zaledwie od dwóch do czterech procent publikowanych w Stanach Zjednoczonych i Wielkiej Brytanii książek, pisze wprost o „samozadowoleniu” świata anglo-amerykańskiego w relacjach z kulturową odmiennością, które gotów jest nazwać „imperializmem za granicą, ksenofobią w kraju"'. Jednak właśnie świat angloamerykański jako kultura centralna, o rozbudowanym rynku wydawniczym, może też sobie pozwolić na liczne publikacje przekładów literatury niekomercyjnej, na przykład poezji, pisarstwa eksperymentalnego albo literatury powstałej w językach mniejszych. Ile w Polsce ukazało się tomów wierszy tureckich, algierskich czy tamilskich? O czym świadczy fakt, że w Ameryce opublikowano więcej książek żyjących poetów polskich niż w Polsce książek żyjących poetów amerykańskich? Poezja polska tłumaczona na angielski ukazuje się dziś w nieporównanie większej liczbie tytułów niż za czasów, gdy triumfy święcił Herbert. Anglojęzyczni czytelnicy mają dziś do wyboru dziesiątki książek poetyckich tłumaczonych z polskiego. W latach, gdy królowało pojęcie „polskiej szkoły poezji”, tych książek było co najwyżej pół tuzina.

Rzeczywistym miernikiem skuteczności transferu w literaturze jest bowiem nie samo ukazanie się książi w przekładzie, ale zainicjowane nim relacje z literaturą języka docelowego, odzwierciedlone między innymi w (a) obecności głosu autora w debatach publicznych, (b) krytycznej recepcji jego twórczości, (c) wpływie na literaturę języka przekładu. Ilościowe, statystyczne dane dla refleksji nad kulturowym transferem nie są szczególnie przydatne. Istotne jest natomiast to, w jakim stopniu tłumaczona literatura jest w kulturze docelowej aktywna. Jak dalece wrosła w kulturowy, literacki krajobraz i jakich dokonała w nim zmian.

Oznaką głębokiego wrośnięcia w ten krajobraz jest z pewnością częstotliwość, z jaką autor z transferu zabiera głos w głównych mediach, niekoniecznie na tematy związane z literaturą. Andrzej Stasiuk pisywał regularnie do „Frankfurter Allgemeine Zeitung", a wiersz Zagajewskiego, w angielskim przekładzie, ukazał się w „New Yorkerze” po ataku na Światowe Centrum Handlu - bardziej jako komentarz do wydarzeń niż utwór literacki i zdecydowanie jako głos „okaleczonego świata”, a nie głos polski czy wschodnioeuropejski. Autor w ten sposób „przyswojony” należy do ponadnarodowego grona autorytetów, publikujących w czołowych pismach, zasiadających w opiniotwórczych gremiach, goszczących w programach telewizyjnych i radiowych, biorących udział w debatach na festiwalach czy w konferencjach. Do takiej aktywności zaprasza go

9 L. Venuti, dz. cyt., s. 17. 
świat obcojęzyczny, kiedy uznaje autora - Umberta Eco czy Aleksijewicz, Kapuścińskiego - nie za reprezentanta włoskiej, białoruskiej czy polskiej kultury, ale kultury powszechnej.

Inną oznaką udanego transferu mogą być nazwiska, którymi posiłkuje się wydawca, reklamując książkę - chodzi tu o publikowane na okładce rekomendacje (blurby), cytowane fragmenty recenzji prasowych, posłowia i przedmowy. Egzotyzm obcojęzycznego dzieła jest oswajany na wiele sposobów. Książka, która według wydawcy w Ameryce czy Wielkiej Brytanii ma szanse wyjść z getta obcojęzyczności, rekomendowana jest przez rozpoznawalne postaci literatury angielskojęzycznej: gwarancje Gombrowiczowi wystawiają Susan Sontag i John Updike (a nie Artur Sandauer), Lema rekomendują Anthony Burgess i Kurt Vonnegut (a nie Jerzy Pilch), tom wierszy Herberta poleca Heaney (a nie Piotr Śliwiński). Rekomendacje oczywiście nie są gwarancją powodzenia, a polskie rekomendacje nie przekreślają szans w Ameryce. Jednak książka rekomendowana przez obcokrajowca (przekłady wierszy Różewicza rekomendował na przykład Jan Miodek) to mimowolny sygnał, że nie znalazła odzewu w literaturze języka przekładu i nie stała się częścią literatury światowej, że ciągle jest czymś z zewnątrz i na zewnątrz, że nadal czeka za drzwiami. Co ciekawe, o ile wydawcy amerykańscy dbają, by tłumaczenia literatury polskiej rekomendowali amerykańscy krytycy i pisarze, o tyle w Polsce skuteczniejszą rekomendacją dla książki wydaje się nadal informacja, że książkę poleca „New York Review of Books", Stephen King czy Barack Obama. Różnica bierze się $\mathrm{z}$ innego waloryzowania obcości: w Polsce sygnałem wartości jest nadal informacja, że zagranica (a zwłaszcza Ameryka) się zachwyca; w Ameryce zachwyty importowane nie robią wrażenia, istotniejsze są rekomendacje swoich. Obcość ciekawi, ale musi być oswojona i podżyrowana.

Drugim ze wspomnianych kryteriów udanego transferu, rzadszym i cenniejszym, jest wpływ na literaturę języka docelowego. W powojennej literaturze polskiej być może tylko Herbert, przeniesiony do angielszczyzny, mógłby się tym pochwalić. Z tym że mimo popularności nie stworzył ani szkoły, ani nurtu, a jego wpływ ma charakter doraźny i zapośredniczony. Ujawnia się akcydentalnie, na przykład w twórczości poetów irlandzkich, takich jak noblista Heaney (kilka wierszy z tomu The Haw Lantern czy elegia napisana po śmierci Herberta). Odzywa się, być może, w wierszach amerykańskiego poety serbskiego pochodzenia, Charlesa Simica - amerykańscy krytycy gotowi byli napisać, że:

pod względem wrażliwości Simic pozostaje poetą wschodnioeuropejskim. Jego złudnie prosty język, wspaniały realizm magiczny jego poetyckich obrazów, nagłe przeskoki, łączą go z poezją Zbigniewa Herberta i Wisławy Szymborskiej ${ }^{10}$.

10 Who's Who in Twentieth-Century World Poetry, red. M. Willhardt, A.M. Parker, London 2000, s. 297. 
Wszedł do twórczości noblisty J.M. Coetzeego, pojawił się w motcie powieści Dona De Lillo. Zainspirował po części Christophera Reida do napisania pastiszowego, „wschodnioeuropejskiego” tomu Katerina Brac. To ślady obecności Herberta, przypadkowo i niewyczerpująco dobrane, ale w poezji angloamerykańskiej nie ma i nie było herbertyzmu, na wzór bajronizmu czy bliższego naszym czasom o'haryzmu.

Przywołałem Franka O’Harę nie bez przyczyny, bo najbardziej znany przykład efektywnego wprowadzenia obcego tekstu w kontekst literatury rodzimej w Polsce to właśnie przekłady O'Hary, a następnie innych poetów związanych ze szkołą nowojorską, zwłaszcza Johna Ashbery’ego. Proponuję na chwilę odwrócić moją tytułową perspektywę. Komunałem byłoby dziś mówić, że przekłady te wpłynęły na postać najnowszej poezji polskiej, że całe pokolenie polskich poetów pisało O'Harą i Ashberym. Równie ewidentnym komunałem byłoby dziś powtarzać, że polski o'haryzm to mit, bo poeci naśladujący O'Harę niewiele z niego rozumieli, a niewiele rozumieli, bo za mało go znali. Że to nie O'Hara podbił językową wyobraźnię polskich o'harystów, ale ich wyobrażenie tego, kim był O’Hara. Musiało minąć wiele lat, by o szkole nowojorskiej zaczęły się ukazywać pogłębione szkice polskich autorów, a do wczesnych, krótkich wierszy O’Hary dołączyły przekłady jego nieoczywistych, hermetycznych poematów.

Dużo ciekawsze w historii polskiego o'haryzmu jest nie tyle liczne grono jego naśladowców, ile pojawienie się niemal równolegle wierszy, które są o'harystycznymi pastiszami (przede wszystkim w twórczości Darka Foksa). Wyrosły one nie z dystansu wobec amerykańskiego poety ani wobec jego popularności w polskiej poezji, ile z uświadomienia sobie, że od ich powstania minęło kilkadziesiąt lat, zmieniły się kulturowe paradygmaty, a świat przeszedł niejedną rewolucję, od kontrkulturowej po informatyczną. Pastisz nie dezawuuje naśladowanego wzorca, podkreśla natomiast różnicę między wzorcem a jego powtórzeniem, wskazuje na niemożność repetycji. O ile stopień nasycenia wierszy Marcina Świetlickiego, Marcina Sendeckiego czy Wojciecha Wilczyka poetyką O'Hary jest kwestią sporną (można wyobrazić sobie rozmowę o ich wierszach, która w ogóle nie przywoływałaby O’Hary), o tyle wpływ amerykańskiego poety na powstanie takich książek Foksa jak Sonet drogi czy Misterny tren wydaje się oczywisty.

Kolejnym, ważkim kontekstem polskiej recepcji O'Hary jest fakt, że poeci polscy naśladowali nie tyle O’Harę, ile polskie przekłady jego wierszy. W stopniu znacznie wyższym niż w wypadku innej amerykańskiej inwazji - tej po roku 1956 - znaczącą rolę odegrał tu przekład, konkretny wysiłek translatorski jednego tłumacza, którego osobowość - a był on uznanym poetą - odcisnęła się wyraźnie na jego wyborach translatorskich. O’Hara przychodził do polszczyzny nie tyle przeniesiony, ile przefiltrowany przez silną, twórczą osobowość Piotra Sommera, naznaczony rytmem i intonacją jego języka. Można porównać to, z zachowaniem proporcji, do Laments, przekładu Trenów Jana Kochanowskiego, jaki we współpracy ze Stanisławem Barańczakiem stworzył irlandzki 
poeta Heaney, znacząc tę poezję irlandyzmami, wprowadzając do niej charakterystyczną dla siebie intonację i formalny kunszt. Nie chodziło o to, że nazwisko znanego poety (Heaneya) gwarantowało jakość poezji nieznanego obcojęzycznego autora (Kochanowski), ale o to, że przekłady tej poezji odbierano jako przedłużenie twórczości poetyckiej tego pierwszego. Prawda jest brutalna: nie wielkość Kochanowskiego zagwarantowała mu miejsce we współczesnym nam kanonie literatury światowej, ale wielkość i międzynarodowe znaczenie jego irlandzkiego współtłumacza. Jest to tom, który na liście jego londyńskiego wydawcy figuruje wśród szesnastu książek poetyckich Heaneya - jedyny jako przekład poety (mimo że w jego bibliografii znajdują się przekłady Wergiliusza, staroangielskiego Beowulfa i Geoffreya Chaucera). Wiersze Kochanowskiego w przekładach Heaneya (wespół z Barańczakiem) i O’Hary w przekładach Sommera czytano nie tylko jako wiersze Kochanowskiego i O'Hary, ale także jako utwory Heaneya i Sommera. Zwrócił na to uwagę Andrzej Sosnowski:

O’Hara [w Polsce - dop. J.J.] w ogóle nie mógłby zaistnieć, gdyby wcześniej nie powstały sprzyjające warunki o znacznie bardziej zasadniczym charakterze. Na przykład, jestem pewien, że większość [polskich - dop. J.J.] autorów, którzy tak polubili O’Harę, wcześniej czytała i lubiła wiersze jego tłumacza ${ }^{11}$.

Innymi słowy: tak jak Laments Kochanowskiego czytali ci, którzy wcześniej sięgali do wierszy Heaneya, tak O’Harę zaczęli czytać ci, którzy wcześniej poznali wiersze Sommera. I czytali je poprzez Sommera, przygotowani do O'Hary przez lekturę wierszy jego tłumacza. To ważny moment w tej historii, odwraca bowiem zbyt oczywistą, zbanalizowaną zależność: to nie tyle O'Hara wpłynął na poezję polską, ile poezja polska wpłynęła na O'Harę. Ewidentną prowokacyjność tego twierdzenia można złagodzić kwalifikacją: nie tylko O’Hara wpłynął na najnowszą poezję polską, ale także najnowsza poezja polska wpłynęła na polskie przekłady O’Hary, które z kolei wpłynęły na poezję polską.

Ale kierunek wpływu może być jeszcze inny niż dwa tu opisane. Jak zauważa Sommer, wprowadzenie O'Hary i nowojorczyków do polszczyzny, a tym samym do polskiego obiegu literackiego, gdzie stali się oni ważnym punktem odniesienia, doprowadziło do odkrycia zapomnianych polskich poetów przeszłości, do reinterpretacji ich twórczości, a w wymiarze ogólnym do przearanżowania kanonu polskiej poezji współczesnej. To w pewnej, znaczącej mierze dzięki O'Harze wprowadzonemu przez Sommera doszło do rewizji kanonu poezji polskiej, w którym miejsce Miłosza i Herberta zajęli Witold Wirpsza, Miron Białoszewski, Tymoteusz Karpowicz, Krystyna Miłobędzka. Sommer, opowiadając o znaczeniu O'Hary dla nowej poezji polskiej, zauważył, że zapewne

11 A. Sosnowski, Trop w trop. Rozmowy z Andrzejem Sosnowskim, wybór, wstęp, oprac. G. Jankowicz, Wrocław 2010, s. 40. 
„O'Hara przydał się i Białoszewskiemu. Bo może za pośrednictwem O’Hary tę pojedynczość w języku zaczęto lepiej rozumieć?”'12.

W eseju Tradycja i talent indywidualny Eliot zanotowat:

kiedy nowe dzieło powstanie, dzieje się coś, co przytrafia się i w stosunku do wszystkich dzieł artyzmu dawniej powstałych. Istniejące zabytki tworzą pewien ład idealny stosunku wzajemnego i ład ten zmieniony zostaje przez wprowadzenie w ten układ nowego (rzeczywiście nowego) dzieła sztuki. (...) ktokolwiek uznaje za słuszną ideę ładu kształtu europejskiej, a tym samym angielskiej literatury, nie dojrzy śmieszności w tym, że przeszłość zmieniona zostaje przez teraźniejszość, w takiej mierze, w jakiej teraźniejszość kierowana jest przez przeszłość ${ }^{3}$.

Eliot pisze o „nowym dziele”, którym - dla naszych potrzeb - może być również przekład dzieła literackiego wprowadzony do obcojęzycznej kultury. Jeśli przekład ten pod wieloma względami - językowym, estetycznym, ideowym - będzie dziełem w tej kulturze „,rzeczywiście nowym”, nie tylko wyznaczy przyszłość, ale także zmieni przeszłość literatury, do której został wprowadzony. To właśnie stało się w literaturze polskiej po wprowadzeniu do niej poezji O’Hary w przekładach Sommera. Ale działo się tu więcej niż Eliot opisał, bo samo dzieło O'Hary uległo przemianie, bowiem czytano je przez pryzmat wierszy Sommera, a potem innych polskich twórców. Możemy mówić tu o procesie, który nazwałbym wielokierunkową osmozą - o wzajemnym, warunkującym istnienie literatury światowej, przenikaniu się dzieła przełożonego i literatury języka przekładu. W wyniku takiej osmozy dokonuje się przearanżowanie zarówno przestrzeni, w której utwór się znalazł, jak i samego przemieszczonego utworu. Przekład staje się aktywnym elementem ładu polskiej literatury, a polska literatura aktywnym czynnikiem współkształtującym przełożone dzieło. Prawdziwy transfer międzykulturowy, wprowadzenie dzieła do literatury światowej, następuje nie wtedy, kiedy dzieło zostaje przełożone, ani nawet wtedy, kiedy zostaje opublikowane, ale dopiero gdy wchodzi w ten proces wielokierunkowej osmozy, odciskając się na literaturze wcześniejszej i przyszłej, a także samo stając się obiektem estetycznych i ideowych przekształceń w dialogu z dziełami literatury języka przekładu.

Idealnym przykładem takiego dzieła poddanego procesowi osmozy w kulturze polskiej jest oczywiście William Szekspir. Za najdobitniejszy dowód stopnia, do jakiego dzieło Szekspira i kultura polska się przenikają, uznajmy spolszczoną formę jego nazwiska (takiego, stosowanego do tej pory spolszczenia nie doczekał się żaden z obcojęzycznych twórców używających alfabetu łacińskiego). Dowodami wzajemnego przenikania się są, przykładowo, szekspirowskie

12 P. Sommer, Ucieczka w bok, Poznań 2016, s. 141.

13 T.S. Eliot, Kto to jest klasyk i inne eseje, tłum. M. Heydel, M. Niemojowska, H. Pręczkowska, M. Żurowski, Kraków 1998, s. 26. 
inspiracje polskich romantyków, Studium o Hamlecie Stanisława Wyspiańskiego czy wreszcie studia Jana Kotta. Prace tego ostatniego wyszły daleko poza granice Polski i także tam współkształtują sylwetkę Szekspira - z lekką przesadą można powiedzieć, że wśród mnogich wizerunków autora Hamleta świat poznał również Szekspira spolonizowanego, czyli Szekspira po osmozie, pisarza, który wyjechał i wraca odmieniony.

Pozwolę sobie na świadomie daleką analogię: podobnie wrócił z zagranicy Krzysztof Penderecki, przeszedłszy przez proces osmozy z brytyjską progresywną muzyką rockową i hollywoodzką muzyką filmową. Również transfer, jakim była międzynarodowa popularność twórczości Kapuścińskiego, może być przykładem, z zachowaniem proporcji, tego samego mechanizmu, z tym że o odwrotnym kierunku działania. Dorobek twórczy przełożony na angielski wpisał się w tamtejszy literacki krajobraz (Kapuścińskiego wydają największe oficyny wydawnicze, pojawia się jako postać w jednej z powieści Salmana Rushdiego, irlandzka poetka Sinéad Morrissey wprowadza go do swojego wiersza, Cesarz książką roku według „Sunday Times” itd.). Twórczość Kapuścińskiego wraca do kultury, która ją wydała - przekształcona przez tamtejszy, obcojęzyczny jej odbiór. To nie polscy krytycy, ale brytyjscy (w osobie Johna Ryle’a), i nie w Polsce, a na anglojęzycznej scenie literackiej, rozpoczęli dyskusję nad faktograficzną akuratnością reportaży Kapuścińskiego, nad jego stosunkiem do prawdy w pisarstwie i do lokalnego szczegółu, podjętą potem przez polskich badaczy twórczości autora Cesarza. Tak działa literatura światowa: należący do niej pisarz wraca do kraju inny, niż z niego wyszedł.

\section{Bibliografia}

Eliot T.S., Kto to jest klasyk i inne eseje, tłum. M. Heydel, M. Niemojowska, H. Pręczkowska, M. Żurowski, Kraków 1998.

Herbert Z., The Collected Poems 1956-1998, tłum., red. A. Valles, New York 2007.

Lubelski T., Prawdziwy partner. Francuska krytyka o Kieślowskim, „Kwartalnik Filmowy" 1993, nr 4.

O’Hara F., Twoja pojedynczość, wybór, tłum., posłowie P. Sommer, Warszawa 1987.

Page-Fort G., Why Do Americans Read so Few Books in Translation?, 3.08.2018, https://lithub.com/why-do-americans-read-so-few-books-in-translation/, dostęp: 11.07.2020.

Quinn J., Between Two Fires: Transnationalism and Cold War Poetry, Oxford 2015. Sommer P., Ucieczka w bok, Poznań 2016.

Sosnowski A., Trop w trop. Rozmowy z Andrzejem Sosnowskim, wybór, wstęp, oprac. G. Jankowicz, Wrocław 2010.

Venuti L., The Translator's Invisibility: A History of Translation, London 1995.

Who's Who in Twentieth-Century World Poetry, red. M. Willhardt, A.M. Parker, London 2000. 